\title{
Seroprevalence of HIV, hepatitis $b$, and hepatitis $c$ among opioid drug users on methadone treatment in the netherlands
}

Imke Schreuder ${ }^{1,2^{*}}$, Marianne AB van der Sande ${ }^{2,6}$, Matty de Wit ${ }^{3}$, Monique Bongaerts ${ }^{4}$, Charles AB Boucher ${ }^{1}$, Esther A Croes ${ }^{5}$, Maaike G van Veen ${ }^{2}$

\begin{abstract}
Background: Injecting drug users (IDU) remain an important population at risk for blood-borne infections such as human immunodeficiency virus (HIV), hepatitis B virus (HBV) and hepatitis C virus (HCV). In the Netherlands, a program is being implemented to offer annual voluntary screening for these infections to opioid drug users (ODUs) screened in methadone care. At two care sites where the program is now operating, our study aimed to estimate the seroprevalence among ODUs screened for HIV, HBV and HCV; to evaluate HBV vaccination coverage; and to assess the feasibility of monitoring seroprevalence trends by using routine annual screening data.

Methods: Opioid drug users on methadone treatment are routinely offered voluntary screening for infectious diseases such as HIV, HBV and HCV. Data on uptake and outcome of anti-HIV, anti-HBC, and anti-HCV screening among ODUs receiving methadone were obtained from two regions: Amsterdam from 2004 to 2008 and Heerlen from 2003 to 2009.

Findings: Annual screening uptake for HIV, HBV and HCV varied from 34 to 69\%, depending on disease and screening site. Of users screened, 2.5\% were HIV-positive in Amsterdam and 11\% in Heerlen; 26\% were HCVpositive in Amsterdam and 61\% in Heerlen. Of those screened for HBV, evidence of current or previous infection (anti-HBc) was found among 33\% in Amsterdam and 48\% in Heerlen. In Amsterdam, 92\% were fully vaccinated for $\mathrm{HBV}$ versus $45 \%$ in Heerlen.

Conclusion: Annual screening for infectious diseases in all ODUs in methadone care is not fully implemented in the Netherlands. On average, more than half of the ODUs in methadone care in Heerlen and Amsterdam were screened for HIV, HBV and HCV. In addition, screening data indicate that HBV vaccination uptake was rather high. While the HIV prevalence among these ODUs was relatively low compared to other drug-using populations, the high HCV prevalence among this group underscores the need to expand annual screening and interventions to monitor HIV, HBV and HCV in the opioid drug-using population.
\end{abstract}

\section{Background}

Injecting drug users (IDU) and opioid drug users (ODUs) remain at high risk for blood-borne infections with human immunodeficiency virus (HIV), hepatitis B virus ( $\mathrm{HBV})$, and particularly hepatitis $\mathrm{C}$ virus (HCV) [1-5]. This is due mainly to high transmission risk associated with the sharing of injection equipment and,

\footnotetext{
* Correspondence: i.schreuder@erasmusmc.nl

'Department of Virology, Erasmus MC, (Dr. Molewaterplein 50), Rotterdam (3000 CA) the Netherlands

Full list of author information is available at the end of the article
}

depending on the virus, to sexual risk behaviour [1-3]. An estimated 25.000 ODUs are currently living in the Netherlands [6-8], of whom approximately $15 \%$ inject drugs. About 12,000 ODUs receive outpatient methadone treatment, which is around 50\% [7]. This treatment is one of many harm reduction interventions, like syringe exchange programs, which began in Amsterdam in 1984 and spread around the country [9]. Methadone was prescribed on a limited scale to morphine addicts as early as 1968 . Methadone distribution programs became more active around 1990, when it became clear that

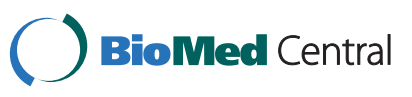


HIV was reaching epidemic levels among drug users in the capital $[7,10]$.

In the Netherlands, harm reduction refers to a range of pragmatic and evidence-based public health policies designed to reduce the harmful consequences of drug use and other high-risk activities [11,12]. Of the opioid drug-using population, roughly $75 \%$ regularly use methadone, as opposed to approximately $40 \%$ ten years ago $[13,14]$. Some use methadone on a regular basis, others only occasionally. The methadone programs are primarily intended for harm reduction rather than drug rehabilitation [14]. A total of 11 institutions for care and treatment of drug users control the management of 85 methadone posts countrywide. They are accessible and free for all patients, as methadone is fully covered under the basic health insurance system. While offering methadone, the posts also facilitate education and monitoring of the drug-using population.

In 2005, national guidelines on opiate maintenance treatment were published to support the quality of methadone care [15]. They included a strong recommendation to screen all methadone users annually for such infectious diseases as HIV, HBV and HCV, and to offer treatment to those who test positive. This recommendation is now being gradually implemented at methadone sites across the country. In addition, HBV vaccination is offered to susceptible drug users, including IDUs and ODUs, through the national Hepatitis B Vaccination Campaign [9].

Previous national studies among ODUs and IDUs showed a high burden of HIV, HBV and HCV [13,16-21], although in recent years, the proportion of IDU among newly diagnosed HIV patients has gradually declined in much of the Netherlands, in association with a decline in injecting $[10,22]$. In 2008, IDU was considered to be the most likely transmission route for $5 \%$ of all registered HIV cases in the country [16]. In 1998, $26 \%$ of the IDU population in and outside methadone care were HIV-positive in Amsterdam [18] and, in the same year, $22 \%$ of the IDU population in Heerlen was HIV-positive [19].

The Netherlands is a low-endemic country with an estimated HBsAg prevalence of $0.3-0.5 \%$, where $\mathrm{HBV}$ transmission is restricted mainly to risk groups [23]. The total number of acute HBV patients reported in the Netherlands is an underestimation of the true number of cases, since less than half of infected individuals have symptoms, and not all patients have been reported [23]. There have been few recent studies of $\mathrm{HBV}$ among Dutch IDUs [9], but available data indicate the prevalence of markers of previous infection is as high as 35\% in The Hague in 2000 [20] and 68\% in Heerlen and Maastricht in 1998 [19]. Since the Netherlands has not implemented universal HBV vaccination, it is important to monitor the effect of the National hepatitis B vaccination campaign at risk groups such as drug users.

For $\mathrm{HCV}$, it was estimated that 60,000 people with chronic HCV live in the Netherlands, with only 5,000 to 10,000 of them being aware of their status [4]. Approximately 50 acute $\mathrm{HCV}$ cases are reported annually, and more than half are associated with drug use in general $[16,17]$. The prevalence of anti-HCV varied between $35 \%$ in Rotterdam in 2003 [20] and 74\% in Heerlen in 1996 [21].

To improve insight into the current burden of infectious diseases among drug users being screened, data can be explored from the annual screening programs now operating at a few methadone posts. We used these data to assess the prevalence among ODUs screened of $\mathrm{HIV}, \mathrm{HBV}$ and $\mathrm{HCV}$ in two different regions, as well as $\mathrm{HBV}$ vaccination coverage. We also assessed the utility of using annual screening data to monitor HIV, HBV and $\mathrm{HCV}$ prevalence in the opioid drug using population.

\section{Methods}

Data on HIV, HBV and HCV screening of opioid drug users (ODUs) were obtained from methadone posts in Amsterdam and Heerlen, the Netherlands. The Dutch definition for problematic ODU is "injecting drug use or using opioids, cocaine and/or amphetamine on a regular base (min 3/week)" [Methadone treatment centres, personal communication 2010] [8]. As in other regions, methadone treatment is dispensed in various programs by GPs and nurses working from multiple locations and mobile units. These two regions were amongst others of interest to the Ministry of Health, Sports and Welfare, in part because their prevalence of $\mathrm{HIV}, \mathrm{HBV}$ and $\mathrm{HCV}$ among IDUs were relatively high $[18,19,21]$. They are also of interest due to their established screening programs, which make data available for study and disease monitoring. However, both regions differ greatly in size and their history of drug use.

In Amsterdam, the capital of the Netherlands, methadone has been prescribed since the 1980s [7], providing substitution treatment to a variety of drug users from all over the country and abroad who have come to the capital for drug use. A relatively large proportion of drug users are immigrants from the Caribbean who are less likely to inject drugs than drug users of Dutch background. An estimated 70-80\% of Amsterdam's drug users are covered by the low-threshold methadone services across the city [7].

In Heerlen, in the southern part of the Netherlands, many drug users reside in adjacent regions in Germany, Belgium, and France. The proportion of those who inject is quite high. A study conducted in Heerlen by Carsauw et al. in 1997 showed that $69 \%$ of the study 
participants had injected drugs during the previous 6 months $[19,21]$. The methadone substitution treatment started in Heerlen around 1997 [24].

Amsterdam started voluntary screening for HIV, HBV and HCV at its methadone posts in 2002. For this study, data from the HIV and HBV screening were available from 2006 to 2008. For HCV screening, results of 20042008 were obtained. Heerlen has been screened for all these infections since 2003. Information from screening of both regions was used to estimate the seroprevalence among ODUs under methadone treatment for all three infections and to assess HBV vaccination coverage. For each client, only most recent screening results were available and included. In addition, a number of individual details were collected (e.g. gender, date of birth, screening and vaccination coverage, test results, start of treatment for HIV, chronic HBV and chronic HCV). Moreover, data on prevalences for Heerlen reflect a longer period of time than data from Amsterdam, which were only based on 2006-2008. Therefore, these prevalences of both HBV and HIV in Amsterdam might be higher if we take into account the positive cases of the years before 2006. No data is collected on modes of drug use. However, from personal communication we know that approximately $60 \%$ in Heerlen and $40 \%$ in Amsterdam has ever injected drugs [Methadone treatment centre Heerlen and Amsterdam, personal communication 2010].

Screening is carried out in collaboration with regional laboratories. To estimate the HIV prevalence, we used data from HIV-antibody tests, provided positive results were confirmed. To assess HBV status, we used data from anti-HBc serological tests. Data on HBsAg status were not available. To assess HCV status, results from anti-HCV tests were available. No data on HCVRNA were available. It should be noted that the antibody tests for $\mathrm{HBV}$ and $\mathrm{HCV}$ indicate exposure to the virus, but cannot determine if ongoing infections are present.

\section{Findings}

In total, 2566 ODUs were registered in methadone care in Amsterdam between 2004 and 2008. Of these, 2024 were (also) registered between 2006 and 2008. In Heerlen, 287 ODUs were in care from 2003-2008.

\section{HIV prevalence}

A large majority (81\%) of HIV-positive ODUs in Amsterdam and Heerlen were male, and by far most (92.5\%) were aged above 40 years (Table 1 ).

In Amsterdam, 1231/2024 (61\%) of the ODUs in care were screened for HIV between 2006 and 2008, and 31/ 1231 (2.5\%) were found positive. In Heerlen, 179/287 (62\%) of those in care were screened for HIV between 2003 and 2008, and 20/179 (11\%) were found positive (Table 2). Those found HIV-positive in Heerlen were all co-infected with $\mathrm{HCV}, 65 \%$ were anti-HBc positive.

\section{HBV prevalence and HBV vaccination uptake}

In Amsterdam, 680/2024 (34\%) of the ODUs in care were screened for HBV from 2006 to 2008. Of these, 225/680 (33\%) had antibodies against HBV (anti-HBc). In total 1469 ODUs were vaccinated against HBV between 2002 and 2008, either full or partially. The estimated vaccination coverage among ODUs in Amsterdam in 2006-2008 was 92\%. Completion of HBV vaccination was unknown.

In Heerlen, 197/287 ODUs (69\%) were screened for HBV between 2003 and 2008, of whom 93 were antiHBc positive (48\%), mostly male. Of all ODUs in care in Heerlen, 130/287 (45\%) persons completed their vaccination course against HBV. Interestingly, of the HIV and $\mathrm{HCV}$-positive individuals, HBV vaccination was completed by $26 \%$ and $25 \%$, respectively. Of all ODUs

Table 1 Demographics of drug users found positive for HIV, HBV and HCV in screening at methadone posts in Amsterdam and Heerlen.

\begin{tabular}{|c|c|c|c|c|c|}
\hline & \multicolumn{2}{|c|}{ HIV } & \multirow{2}{*}{$\begin{array}{c}\text { HBV (anti-HBC) } \\
\text { Heerlen }^{* *}\end{array}$} & \multicolumn{2}{|c|}{ HCV (anti-HCV) } \\
\hline & Amsterdam* & Heerlen $^{* *}$ & & Amsterdam*** & Heerlen** \\
\hline & $N=31$ & $N=20$ & $\mathbf{N}=93^{\xi}$ & $N=227$ & $N=115$ \\
\hline \multicolumn{6}{|l|}{ Gender: } \\
\hline - Male & $21(67 \%)$ & 19 (95\%) & $65(70 \%)$ & $233(67 \%)$ & $80(70 \%)$ \\
\hline - Female & $10(33 \%)$ & $1(5 \%)$ & $28(30 \%)$ & 117 (33\%) & $35(30 \%)$ \\
\hline \multicolumn{6}{|c|}{ Age (years): } \\
\hline$-<30$ & $1(3 \%)$ & 0 & $2(2 \%)$ & $5(1 \%)$ & $4(3 \%)$ \\
\hline$-30-39$ & $2(7 \%)$ & $1(5 \%)$ & $7(8 \%)$ & $51(15 \%)$ & $13(11 \%)$ \\
\hline$-40-49$ & $19(61 \%)$ & $14(70 \%)$ & $47(50 \%)$ & 170 (49\%) & $65(57 \%)$ \\
\hline$-\geq 50$ & $9(29 \%)$ & $5(25 \%)$ & 37 (40\%) & $124(35 \%)$ & $33(29 \%)$ \\
\hline
\end{tabular}

*Data of 2006-2008, **Data of 2003-2008, ***Data of 2004-2008.

${ }^{\xi}$ No data on demographics for HBV in Amsterdam were available. 
Table 2 Seroprevalence of HIV in the two regions.

\begin{tabular}{lccc}
\hline & $\begin{array}{c}\text { Number in } \\
\text { methadone care }\end{array}$ & $\begin{array}{c}\text { HIV screening } \\
\text { coverage } \\
\mathbf{N}(\%)\end{array}$ & $\begin{array}{c}\text { HIV } \\
\text { prevalence } \\
\mathbf{N}(\%)\end{array}$ \\
\hline Amsterdam* $^{*}$ & 2024 & $1231(61 \%)$ & $31(2.5 \%)$ \\
Heerlen** & 287 & $179(62 \%)$ & $20(11 \%)$ \\
\hline
\end{tabular}

*Data of 2006-2008, **Data of 2003-2008

in care who were not vaccinated ( $\mathrm{n}=157), 22$ stated they did not want to get the vaccination; 46 started vaccination but have not yet had their second and/or third vaccine (Table 3 ).

\section{HCV prevalence}

Among the HCV-positive ODUs in Amsterdam and Heerlen, $70 \%$ were male and $86.5 \%$ were aged 40 years and above (Table 1).

In Amsterdam, 1359/2566 (53\%) of the ODUs in care were screened for HCV from 2004 to 2008, and 350/ 1359 (26\%) were positive for HCV antibodies. In 2008, 53/350 (15\%) HCV-positive ODUs started treatment. In Heerlen, 190/287 (66\%) of ODUs in care were screened for HCV between 2003 and 2008, and 115/190 (61\%) were positive. Of these, 55 (48\%) have started $\mathrm{HCV}$ treatment (Table 4).

\section{Discussion}

It has been possible to establish routine screening programs for HIV, HBV and HCV among ODUs in methadone care in the Netherlands. Expanding annual screening programs and strengthening coverage will enable improved care for this vulnerable group, and can provide relevant surveillance data to monitor these epidemics among ODUs. Initial results from this screening program show that a significant group, primarily for HBV, do not yet receive such screening. For HBV, this could be affected given that a specific group of drug users, such as IDUs and ODUs, should get vaccinated as part of the national hepatitis B vaccination campaign [23].

Among those screened in two regions, HIV prevalence was relatively low in Amsterdam (2.5\%) but higher in Heerlen (11\%). Of those screened for HBV, evidence of current or previous infection (anti-HBc) was found among 33\% in Amsterdam and 48\% in Heerlen HBV vaccination coverage was relatively high in Amsterdam (92\%) but only $45 \%$ in Heerlen. The prevalence of anti-
$\mathrm{HCV}$ was higher than HIV, ranging from $26 \%$ in Amsterdam to $61 \%$ in Heerlen.

In the past, studies among drug users in and outside methadone treatment in Amsterdam have demonstrated HIV prevalences higher than our finding [18]. Previous cross-sectional surveys among IDU in Heerlen found HIV prevalences of $16.3 \%$ in 1996 and $21.6 \%$ in 1998. These prevalences are also higher compared to our finding of $11 \%$ [19-21], however these studies were restricted to IDUs only whereas our study focused on ODUs, including those injecting drugs. Behavioural surveys have shown that injecting drugs has decreased and is now less popular [10,22], which could explain part of these differences. In addition, in comparison to crosssectional studies, testing in a treatment setting has been performed selectively for those not already known to be HIV-infected. Finally, the population of ODUs who still inject is aging, and many HIV-infected drug users have died in the last decade, which can also result in lower HIV prevalence.

Although a direct comparison with previous studies is not possible, the higher HIV prevalence found by other studies may reflect another drug user's population that is recruited outside methadone treatment settings. These users may have a higher burden of HIV than those in care. Moreover, studies have shown that methadone treatment is associated with a lower risk of HIV infection, probably by discouraging injecting and encouraging better knowledge of risk factors [25,26].

The current HIV prevalence among ODUs in our study is comparable to trends of other western European countries. However, in Eastern Europe and outside of Europe, HIV rates have increased in recent years [27] and suggest an increasing incidence of HIV infection among people who inject drugs [28]. Alertness on possible re-emergence of HIV among drug users in the Netherlands is therefore essential to prevent relapse.

In 2000, more than half of the persons in a methadone clinic population in America had evidence of HBV exposure [29]. In this study, the proportion of persons who ever injected drugs was $78.7 \%$. Our data, indicating both past and acute infections, shows comparable results. In the UK, the overall seroprevalence of exposure markers for $\mathrm{HBV}$ (anti-HBc) was $48 \%$ among ODUs in and outside the methadone setting [30]. However, this study was conducted many years earlier.

Table 3 Seroprevalence of HBV and vaccination coverage in the two regions

\begin{tabular}{lccc}
\hline & $\begin{array}{c}\text { Number in } \\
\text { methadone care N }\end{array}$ & $\begin{array}{c}\text { HBV screening } \\
\text { coverage N (\%) }\end{array}$ & $\begin{array}{c}\text { HBV prevalence } \\
\text { anti-HBc N (\%) }\end{array}$ \\
\hline Amsterdam* $_{\text {Heerlen** }}^{*}$ & 2024 & $680(34 \%)$ & $225(33 \%)$ \\
coverage N (\%)
\end{tabular}

*Data of 2006-2008, ${ }^{* *}$ Data of 2003-2008, ${ }^{* * *}$ Data of 2002-2008. 
Table 4 Seroprevalence of $\mathrm{HCV}$ in the two regions.

\begin{tabular}{|c|c|c|c|}
\hline & $\begin{array}{c}\text { Number in } \\
\text { methadone care }\end{array}$ & $\begin{array}{c}\text { HCV } \\
\text { screening } \\
\mathrm{N}(\%)\end{array}$ & $\begin{array}{c}\mathrm{HCV} \\
\text { prevalence } \\
\mathrm{N}(\%)\end{array}$ \\
\hline Amsterdam* & 2566 & 1359 (53\%) & $350(26 \%)$ \\
\hline $\begin{array}{l}\text { - starting } \\
\text { treatment }^{1}\end{array}$ & & & 53 (15\%) \\
\hline Heerlen** & 287 & $190(66 \%)$ & 115 (61\%) \\
\hline $\begin{array}{l}\text { - starting } \\
\text { treatment }\end{array}$ & & & 55 (48\%) \\
\hline
\end{tabular}

'Obtained from the Dutch-C project of the public health centre in Amsterdam within the Amsterdam Cohort Studies among drug users, *Data of 2004-2008, **Data of 2003-2008

For the current study, only data from anti-HBc serological tests were available to assess HBV prevalence among those who are screened, unfortunately no data on HBsAg status were available. In case of a positive anti-HBc test, it is recommended to also assess the HBsAg status to identify and consequently interrupt the risk for individual transmission, as well as transmission on population level.

Our study showed a reasonably high number of ODUs completing their vaccine course for HBV, however, vaccination must still be increased further for Heerlen $[30,31]$. Besides protecting against HBV, it may help drug users to develop a stronger pro-health attitude, leading to less $\mathrm{HCV}$-related risk behaviour, according to Quaglio et al [31]. By November 2009, the national Hepatitis B Vaccination Campaign in the Netherlands had estimated vaccination coverage of approximately 15,000 drug users, of whom approximately $60 \%$ completed their three-part vaccination within 6 months $[23,32]$.

The prevalence of $\mathrm{HCV}$ in this study is lower than found by international studies conducted in comparable methadone settings from 1999 to 2004. Those studies show an overall prevalence of $67-96 \%[5,29,33-36]$ and even higher prevalence among drug users who inject drugs (around 95\%). Our results are compatible with studies conducted outside methadone settings in 20062007, which found prevalences of 40-70\% in samples from Bulgaria, Georgia, Germany, France, Italy, Poland, and Ukraine, with prevalence of $80-90 \%$ in Germany, France, Italy, Poland, Romania, and Spain [4,27]. Moreover, the proportion of $\mathrm{HCV}$-positive individuals starting $\mathrm{HCV}$ treatment is fairly high in our study, particularly in Heerlen, compared to studies that show proportions of $6 \%, 9 \%$, and $35 \%$ [37-39].

The variation in the proportion starting HCV treatment between the two regions (48\% vs. $15 \%$ ) might be explained by several factors. First, starting HCV treatment is a time consuming process and requires much personal capacity. The absolute number of ODUs screened for $\mathrm{HCV}$ in methadone care in Amsterdam is
7 times higher compared to Heerlen, however, the actual number of persons who started $\mathrm{HCV}$ treatment is comparable in both centres. Secondly, $95 \mathrm{HCV}$ positive (and HIV negative) persons in Amsterdam are currently in anticipation of a new, and probably more effective, drugs to start HCV treatment [Methadone treatment centre, personal communication 2010].

The most common contributors to the relatively low levels of treatment rates for $\mathrm{HCV}$ are the strict criteria to start treatment, which are similar between the two centres [Methadone treatment centre Amsterdam and Heerlen, personal communication 2010], insufficient knowledge among drug users, unwillingness to face side effects (e.g. depression), lack of initial evaluation and adherence to additional appointments [37-39]. It is therefore of highly importance to improve the understanding of $\mathrm{HCV}$ status and $\mathrm{HCV}$ transmission among drug users.

Possible explanations for the persistently higher prevalence of HIV, HBV and HCV in Heerlen compared to Amsterdam could be the ongoing higher level of injecting drug use and related risk behaviour (e.g. borrowing of syringes) combined with the influx of HIV-positive drug users from adjacent regions and countries [21]. National drug monitoring in the Netherlands has found injecting drug use more popular in the southern region than in others (19\% vs. 10\%) [39]. Moreover, we have presented the HIV and HBV prevalence for Heerlen that reflect a longer period than data from Amsterdam, which were only based on 2006-2008. The prevalence of both HBV and HIV in Amsterdam might be higher if we also take into account the positive cases of the years before 2006.

Our study results should be interpreted in the context of a number of limitations. The implementation of screening for infectious diseases has been conducted differently in the two study regions, perhaps creating differences between their data. In addition, differences might seem exaggerated because data were missing from enough surrounding regions to provide context. Besides this, it would be of interest to also collect data on risk factors such as routes of administration of drug use, needle sharing and sexual risk behaviour. Based on the available data collected in Heerlen en Amsterdam, however, this was not possible. We therefore recommend collecting such data in the voluntary infectious disease screening.

Another limitation is that we only targeted ODUs in our study, whereas other subgroups of drug users may be at risk of infectious diseases as well. However, in the Netherlands, the injection of drugs has decreased substantially in the last years [6-8] and injection of crack is rare. Moreover, most IDUs are included in opioid substitution programs. 
Finally, the availability of data on HBV and HCV-antibody tests only made it not possible to distinguish whether infections have been cleared or remain active. Following infection, less than 5\% of HBV infected adults develop chronic HBV infection, regardless if a person injects drugs [40]. Twenty-five to fifty percent of IDUs develop acute hepatitis C [1]. IDUs with a chronic HBV infection and acute HCV infections are the groups in need of medical evaluation and the groups to target to interrupt ongoing transmission.

In conclusion, annual screening for infectious diseases of ODUs in methadone care is not fully implemented in the Netherlands. However, two regions with such implementation have generated data for assessing the prevalence of infectious diseases. Although collecting data should be improved to use screening results for monitoring trends, they show a relatively low HIV and HBV prevalence among ODUs screened, but it is evident that the $\mathrm{HCV}$ prevalence is high. We therefore recommend enhancing the implementation of voluntary infectious disease screening in all methadone treatment settings nationwide. Drug users who are diagnosed positive can be provided with early treatment, which will benefit them while also reducing further transmission. Furthermore, since many ODUs are not in methadone care, it is of importance to raise awareness about $\mathrm{HCV}$ and facilitate its early diagnosis among incarcerated drug users and others outside the methadone setting. Harm reduction interventions and early detection of new HIV, $\mathrm{HBV}$, and $\mathrm{HCV}$ infections are of vital importance to provide adequate treatment which can interrupt ongoing transmission and lead to a general gain in health benefit.

\section{List of abbreviations}

EMCDDA: European Monitoring Centre for Drugs and Drug Addiction; HBV: Hepatitis B Virus; HCV: Hepatitis C Virus; HIV: Human Immunodeficiency Virus; IDU: Injecting Drug User; IDUS: injecting drug users; ODU: opioid drug use; ODUS: opioid drug users; RIOB: Richtlijn Opiaat Onderhoud Behandeling; RIVM: Rijksinstituut voor Volksgezondheid en Milieu (national institute for public health and the environment).

\section{Acknowledgements}

The authors wish to thank Gerrit van Santen of the Health Service Amsterdam for his contributions. Trui Scheurs, Henny Fijen, and José Ladenstein from Mondriaan in Heerlen are acknowledged for their valuable advice on addictive care and contribution to the study.

\section{Author details}

'Department of Virology, Erasmus MC, (Dr. Molewaterplein 50), Rotterdam (3000 CA) the Netherlands. ${ }^{2}$ Department of Epidemiology and Surveillance, Centre for Infectious Disease Control, National Institute of Public Health and Environment, (Antonie van Leeuwenhoeklaan 9) Bilthoven (3721 MA), the Netherlands. ${ }^{3}$ Department of Epidemiology, Documentation and Health Promotion, Public Health Service, (Nieuwe Achtergracht 100) Amsterdam

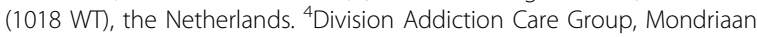
centre, (Valkenburgerweg 17) Heerlen (6411 BM), the Netherlands.

5 Department of Prevention, Trimbos-institute, (Da Costakade 45) Utrecht (3521 VS), the Netherlands. ${ }^{6} J u l i u s$ Centre for Health Sciences and Primary Care, University Medical Centre Utrecht, (Heidelberglaan 100) Utrecht (3508 $\mathrm{GA})$, the Netherlands.

\section{Authors' contributions}

IS and MvV carried out the study; have made substantial contributions to conception and design, acquisition of data, and analysis and interpretation of data; and contributed to the manuscript. MvdS and CB have been involved in drafting the manuscript or revising it critically for important intellectual content. MB, MdW and EC all provided information on the infectious diseases screening and have given final approval of the version to be published.

All authors have read and approved the final manuscript for publication.

\section{Competing interests}

The authors declare that they have no competing interests.

Received: 12 March 2010 Accepted: 26 October 2010

Published: 26 October 2010

\section{References}

1. Hagan H, Thiede H, Weiss NS, Hopkins SG, Duchin JS, Alexander ER: Sharing of Drug Preparation Equipment as a Risk Factor for Hepatitis C. American Journal of Public Health 2001, 91:1.

2. Mathei C, Buntinx F, Damme van P: Seroprevalence of hepatitis C markers among intravenous drug users in western European countries: a systematic review. Journal of Viral Hepatitis 2002, 9(3):157-173.

3. Murrill CS, Weeks H, Castrucci BC, Weinstock HS, Bell BP, Spruill C, Gwinn M: Age-Specific Seroprevalence of HIV, Hepatitis B Virus, and Hepatitis C Virus Infection Among Injection Drug Users Admitted to Drug Treatment in 6 US Cities. American Journal of Public Health 2002, 92(3):385-387.

4. Merkinaite S: HCV infection in Europe. World Hepatitis Awareness Day (WHAD): October 1st 2007; Brussels Eurasian Harm Reduction Network; 2007.

5. European Monitoring Centre for Drugs and Drug Addiction: HIV among IDUs in Europe: increasing trends in the East. EMCDDA, Lisbon; 2009.

6. Rodenburg G, Spijkerman R, Eijnden van den R, Mheen van de D: Nationaal prevalentieonderzoek middelengebruik 2005. Instituut voor Onderzoek naar Leefwijzen \& Verslaving. IVO, Rotterdam; 2007

7. Driessen F, Noorlander E: Handboek verslaving Houten/Diegen: Bohn Stafleu van Loghum; 2004, [in Dutch].

8. Netherlands Institute for Mental Health and Addiction: National drug monitor, annual report 2009 Trimbos Institute, Utrecht; 2010.

9. Trimbosinstituut factsheet: Infectieziekten en druggebruik in Nederland. Netherlands institute for mental health and addiction (Trimbosinstitute); 2007, [in Dutch]

10. van Ameijden EJ, Coutinho RA: Large decline in injecting drug use in Amsterdam, 1986-1998: explanatory mechanisms and determinants of injecting transitions. J Epidemiol Community Health 2001, 55(5):356-63.

11. Marlatt AG: Harm Reduction: Pragmatic Strategies for Managing High-Risk Behaviors Ney York: Guilford Press; 2002.

12. van den Berg C, Smit C, van Brussel G, Coutinho R, Prins M: Full participation in harm reduction programs is associated with decreased risk for human immunodeficiency virus and hepatitis $C$ virus: evidence from the Amsterdam Cohort Studies among drug users. Addiction 2007 102(9):1454-1462.

13. Drugs policy in the Netherlands. [http://www.healthlaw.nl/drugs1.html]

14. Buster MCA, Brussel van GHA, Brink van den W: Estimating the number of opiate users in Amsterdam by capture recapture; the importance of case definition. European journal of epidemiology 2001, 17:935-42.

15. Loth CA, Oliemeulen EAP, Jong de CAJ: Richtlijn opiaat Onderhoudsbehandeling (RIOB). Amersfoort; 2005, [in Dutch].

16. Koedijk F, Vriend HJ, van Veen MG, Op de Coul ELM, van den Broek IVF, van Sighem Al, Verheij RA, van der Sande MAB: Sexually Transmitted Infections, including HIV, in the Netherlands in 2008. RIVM annual report 210261005/2009 Bilthoven; 2009.

17. National coordination for infectious diseases control: $\mathrm{LCl}$ protocol Hepatitis $\mathrm{C}$ RIVM, Bilthoven; 2005, [in Dutch].

18. Beuker RJ, Berns MPH, van Rozendaal CM, Snijders BM, van Ameijden EJC, Houweling H, van de Laar MJW: Surveillance van HIV-infectie onder injecterende druggebruikers in Nederland: meting Amsterdam 1998. RIVM rapport 441100011 Bilthoven; 1999, [in Dutch]

19. Beuker RJ, Berns MPH, van Rozendaal CM, Snijders BM, Jansen M, Hoebe CJPA, van de Laar MJW: Surveillance van HIV-infectie onder injecterende druggebruikers in Nederland: meting Heerlen/Maastricht 1998/1999. RIVM rapport 441100014 Bilthoven; 2001, [in Dutch]. 
20. Beuker RJ, Berns MPH, Watzeels JCM, Hendriks VM, de Coster EJM, van der Marel TE, van de Laar MJW: Surveillance van HIV-infectie onder injecterende druggebruikers in Nederland: meting Den Haag 2000. RIVM rapport 441100015 Bilthoven; 2001, [in Dutch].

21. Carsauw HHC, van Rozendaa CM, Scheepens JMFA, Hoebe CJPA, Meulders WAJ, Jansen M, Dorigo-Zetsma JW, Houweling H: Infecties met HIV, HBV en HCV onder injecterende druggebruikers in Heerlen/ Maastricht. RIVM rapport 441100006 Bilthoven; 1997, [in Dutch].

22. de Boer IM, Op de Coul ELM, Beuker RJ, de Zwart O, Al Taqatqa W, van de Laar MJW: Trends in HIV-prevalentie en risicogedrag onder injecterende druggebruikers in Rotterdam, 1994-2002. Ned Tijdschr Geneeskd 2004, 148(47), [in Dutch].

23. van Houdt R, Koedijk FHD, Bruisten SM, Op de Coul ELM, Heijnen MLA, Waldhober OO, Veldhuijzen IK, Richardus JH, Schutten M, van Doornum GJJ: Hepatitis $B$ vaccination targeted at behavioural risk groups in the Netherlands: Does it work? Vaccine 2009, 27:3530-3535.

24. Lelij van der B, Driessen FMHM: Een onderzoek van aanbod en gebruik bij instellingen die deelnemen aan het heroïneverstrekkingsexperiment Bureau Driessen, Sociaal Wetenschappelijk Onderzoek: Utrecht; 1998 [http://www.bureaudriessen.nl/publicaties/slot-her.html], [in Dutch].

25. Serpelloni G, Carrieri MP, Rezza G, Morganti S, Gomma M, Binkin N: Methadone treatment as a determinant of HIV risk reduction among injecting drug users: a nested case-control study. AIDS Care 1994, 6(2):215-20.

26. Gibsona DR, Flynn NM, McCarthy JJ: Effectiveness of methadone treatment in reducing HIV risk behavior and HIV seroconversion among injecting drug users. AIDS 1999, 13:1807-1818.

27. European Monitoring Centre for Drugs and Drug Addiction: Annual report: the state of the drug problem in Europe. EMCDDA, Lisbon; 2009.

28. Wiessing L, Laar van de MJ, Donoghoe MC, Guarita B, Klempova D, Griffiths P: HIV among injecting drug users in Europe: increasing trends in the East. Eurosurveillance, rapid communications 2008, 13(50).

29. Strauss SM, Astone JM, Hagan H, Des Jarlais DC: The content and comprehensiveness of hepatitis $C$ education in methadone maintenance and drug-free treatment units. J Urban Health 2004, 81(1):38-47.

30. Lamden KH, Kennedy N, Beeching NJ, Lowe D, Morrison CL, Mallinson H, Mutton KJ, Syed Q: Hepatitis B and hepatitis $C$ virus infections: risk factors among drug users in Northwest England. Journal of Infection 1998, 37:260-269.

31. Quaglio GL, Lugoboni F, Pajusco B, Sarti M, Talamini G, Lechi A, Mezzelani $P$, Des Jarlais DC: Factors associated with hepatitis $C$ virus infection in injection and noninjection drug users in Italy. Clin Infect Dis 2003, 37:33-40.

32. van Dam M: National Institute for the Environment and Health, department of Personal communication. 2009.

33. Carter H, Robinson G, Hanlon C, Hailwood C, Massarotto A: Prevalence of hepatitis $B$ and $C$ infection in a methadone clinic population: implications for hepatitis B vaccination. N Z Med J 2001, 114(1136):324-6.

34. McCarthy JJ, Flynn N: Hepatitis $C$ in methadone maintenance patients: prevalence and public policy implications. J Addict Dis 2001, 20(1):19-31.

35. Litwin AH, Soloway I, Gourevitch MN: Integrating services for injection drug users infected with hepatitis $C$ virus with methadone maintenance treatment: challenges and opportunities. Clin Infect Dis 2005, 40(Suppl 5): S339-45.

36. Novick DM, Kreek MJ: Critical issues in the treatment of hepatitis C virus infection in methadone maintenance patients. Addiction 2008, 103(6):905-18.

37. Taylor LE: Delivering Care to Injection Drug Users Coinfected with HIV and Hepatitis C Virus. Clinical Infectious Diseases 2005, 40:S355-61.

38. Mehta SH, Genberg BL, Astemborski J, Kavasery R, Kirk GD, Vlahov D, Strathdee SA, Thomas DL: Limited uptake of hepatitis $C$ treatment among injection drug users. J Community Health 2008, 33(3):126-33.

39. Broers B, Helbling B, François A, Schmid P, Chuard C, Hadengue A, Negro F: Barriers to interferon- $a$ therapy are higher in intravenous drug users than in other patients with acute hepatitis C. Journal of Hep 2005, 42(3):323-328.

40. National coordination for infectious diseases control: $L C l$ protocol Hepatitis $B$ RIVM, Bilthoven; 2008, [in Dutch]. doi:10.1186/1477-7517-7-25

Cite this article as: Schreuder et al:: Seroprevalence of HIV, hepatitis b, and hepatitis $\mathrm{c}$ among opioid drug users on methadone treatment in the netherlands. Harm Reduction Journal 2010 7:25.

\section{Submit your next manuscript to BioMed Central and take full advantage of:}

- Convenient online submission

- Thorough peer review

- No space constraints or color figure charges

- Immediate publication on acceptance

- Inclusion in PubMed, CAS, Scopus and Google Scholar

- Research which is freely available for redistribution

Submit your manuscript at www.biomedcentral.com/submit
Biomed Central 